\title{
Effects of bamboo substrate and supplementary feed on growth and production of the African catfish, Clarias gariepinus
}

\author{
*AMISAH, S; ADJEI-BOATENG, D., AFIANU, D. D. \\ Department of Fisheries and Watershed Management, Kwame Nkrumah University of Science \& Technology, Kumasi, Ghana \\ e-mailsteveamisah1@yahoo.co.uk
}

\begin{abstract}
The effects of bamboo poles as substrate for periphyton development on the growth and production of the African catfish, Clarias gariepinus, was evaluated over a period of 90 days. Three treatments, namely manure application as control $(\mathrm{C})$, control and substrate installation $(\mathrm{C}+\mathrm{S})$ and, control and substrate with supplementary feeding $(\mathbf{C}+\mathrm{S}+\mathrm{F})$ were randomly allotted to six earthen ponds each with an area of $100 \mathrm{~m}^{2}$. Catfish fingerlings of mean weight $27.5 \mathrm{~g} \pm 1.25$ were stocked at the rate of 80 fish per $100 \mathrm{~m}^{2}$. Water temperature, $\mathrm{pH}$, Total Alkalinity, Total Dissolved Solids (TDS), ammonia and nitrites were monitored during the study. The results obtained after a 90day culture period indicated no significant variations in water quality between treatments. Similarly, there were no significant difference in survival between the treatments which ranged from $81.3 \%, 96.8 \%$ and $86.3 \%$ for the $\mathrm{C}, \mathrm{C}+\mathrm{S}$ and $\mathrm{C}+\mathrm{S}+\mathrm{F}$ respectively. The mean gross fish yield $\left(\mathrm{kg} / 100 \mathrm{~m}^{2}\right)$ varied from $16.0 \mathrm{~kg}$ for $\mathrm{C}+\mathrm{S}, 9.5 \mathrm{~kg}$ for $\mathrm{C}+\mathrm{S}+\mathrm{F}$ and $6.0 \mathrm{~kg}$ for $\mathrm{C}$. the study indicated bamboo poles as substrate for periphyton was a superior alternative to improve catfish production under pond conditions. @ JASEM
\end{abstract}

The demand for fish in Ghana is increasing in response to the health benefits of fish and increasing human population. The relatively lower cost of fish compared to beef, chicken or mutton is also a contributory factor to the rising demand as most people can easily afford to buy fish or fish products. Fish is consumed by both rural and urban populations and it contributes about $60 \%$ of the animal protein intake of Ghanaians. Fish consumption per capita in Ghana is known to be as high as $20 \mathrm{~kg}$ compared to the world average of $13 \mathrm{~kg}$ per capita (MOFA, 2004). The expected fish demand in Ghana for 2007 is 913,992 tonnes. With the present production level of 511,836 tonnes per annum, there is an outstanding deficit of 402,156 tonnes (Mensah et. al., 2003). Although, fish is on high demand nationwide, consumption is greatly limited by insufficient production and supply. The Ghana government imports an additional USD 200 million worth of fish to meet the ever increasing domestic market demand. In pursuit of the national agenda to ensure responsible fisheries, food security and poverty alleviation through fish production to meet domestic consumption and for export, there is the need to focus on aquaculture since it has the potential to supplement the output from capture fisheries to meet domestic consumption and for export. Intensive aquaculture requires inputs that are frequently beyond the means of resource-poor rural farmers. Periphyton-based aquaculture can be practised wherever fish farming is possible (Azim et. al., 2001). It is considered the best practice of fish farming since it requires only cheap and readily available inputs, yet highly efficient. It is a flexible technique that originated from indigenous knowledge of brush park fisheries where bushy tree branches installed in water bodies served as a device for attracting fish for harvesting (Welcomme, 1972).
From a theoretical viewpoint, the advantages conferred by adding substrate to an aquaculture system is an increase in the energy and nutrient transfer efficiencies of the system owing to the additive effects of the periphyton and phytoplanktonbased components of production. Herbivorous fish generally require larger-sized food sources such as benthic algae, alga-based detritus or higher aquatic plants, which can be harvested more efficiently as well as zooplankton to supplement the intake of phytoplankton by omnivorous fish. Hard substrates such as bamboo and other tree branches, which are generally absent in traditional fish ponds are essential component of the periphyton-based aquaculture for inducing bacterial and zooplanktonic biomass associated with alga growth. This abundant natural food is exploited directly by many herbivorous and omnivorous fish as a basic source of food (Azim et. al., 2001).

In this study, a system of periphyton-based aquaculture was considered as an alternative to fish production in conventional, substrate-free, pond. The design of treatments focused primarily on improving fish yield through the use of minimal quantity of substrates, optimal level of fertilization with organic manure that will compensate for the small quantity of substrate used by inducing enough natural production, and the application of supplementary feed. Monoculture of an indigenous farmed species, catfish, was used with the principal aim of improving fish production in aquaculture systems. Against this background the study was conducted in order to Evaluate the effects of bamboo substrate and supplementary feed on the growth performance of the African catfish, Clarias gariepinus and assess the potential of periphyton-based aquaculture in improving fish production. 


\section{MATERIALS AND METHODS}

The experiment was conducted in six earthen ponds at the experimental fish farm of the Department of Fisheries and Watershed Management of the Kwame Nkrumah University of Science \& Technology, Kumasi, Ghana. The experiment consisted of three treatments: Control (C), control and substrate installation $(\mathrm{C}+\mathrm{S})$, and control and substrate with supplementary feeding $(\mathrm{C}+\mathrm{S}+\mathrm{F})$. The control treatment consisted of fertilization with pig manure that runs through all ponds at the same rate. The second treatment, which was control with bamboo installation at the density of 4 poles per $\mathrm{m}^{2}$, provided an additional mean surface area of $73.28 \mathrm{~m}^{2}$. The effect of these treatments on the culture system as well as yield of cultured species was examined at the end of a 90-day culture period between December, 2006 and February, 2007. Three $200 \mathrm{~m}^{2}$ earthen ponds were each partitioned with nylon nets into two to make up for the six ponds for the experiment. Each pond had an area of $100 \mathrm{~m}^{2}$ with an effective water surface area of $80 \mathrm{~m}^{2}$ and mean depth of $50 \mathrm{~m}$. Ponds were sun and air dried for three weeks, and planted with bamboo poles with mean diameters of $9.0 \mathrm{~cm}$ and mean lengths of $90.0 \mathrm{~cm}$. Bamboo poles were driven vertically into the pond bottom at 1 metre intervals, and yielded a total submerged area of 73.25 $\mathrm{m}^{2}$ per pond (Plate 1). Ponds labeled as 1, 2, 3 and 5 received the substrate treatments while ponds labeled as 4 and 6 were without bamboo poles.

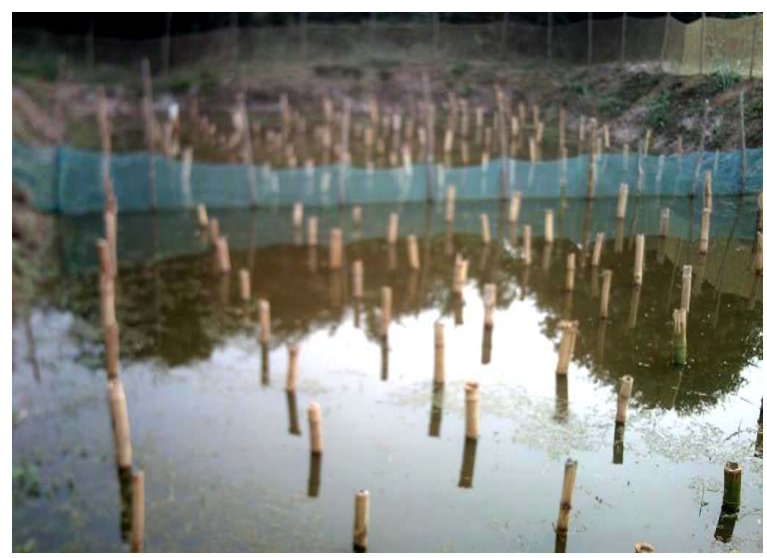

Plate 1.An experimental pond with installed bamboo poles at $1 \mathrm{~m}$ intervals

\section{Fish stocking and feeding}

Ponds were stocked with catfish fingerlings at a density of 80 fish per pond. Fingerlings were obtained from nearby hatchery and acclimatized in ponds on the farm. On November, 29, 2006, fingerlings were sampled and weighed. Clarias species fingerlings (mean weight $27.5 \pm 1.25 \mathrm{~g}$ ) were released into the ponds between the hours of 09:00 and 12:00 GMT. Supplemental feeding at the rate of $5 \%$ per pond biomass per day was applied in pond 1 and 3 using a mixture of wheat bran and groundnut husk at a ratio of 3 parts groundnut husk to 1 part wheat bran. Feeding started on the second day after stocking and was administered twice daily between 08:30 and 16:30. Feed measurements were taken using an electronic meter, Acculab V600 Model. Subsequent feeding rates were done by sampling fish (20-50\% biomass) from control ponds and the necessary adjustments effected. Initial fertilisation of $20 \mathrm{~kg}$ pig manure per pond was applied 15 days prior to stocking. Subsequent fertilisation was done fortnightly using pig manure in all the ponds at a rate of $5-10 \mathrm{~kg}$ per pond. Subsequent fertilization rates were done based on the turbidity of the water which was determined using a Secchi disc. Water depths were monitored throughout the experiment, and regularly filled up to compensate for evaporative losses. Physicochemical characteristics including transparency, temperature, $\mathrm{pH}$, alkalinity, total dissolved solids, iron, nitrate-nitrogen, and ammonium-nitrogen levels were monitored. At the end of the experiment all substrates were removed, ponds drained, and all fish harvested. Data were collected on:

Gross production; i.e.,

i. Total bulk weight and number by species harvested per pond.

ii. Mean weight of species by pond

iii. Survival percentage (mortality) by species per pond.

Specific growth rate was determined as, SGR $=[$ In (final weight)- In (initial weight)] /culture period $\mathrm{x} 100$

\section{Statistical Analyses}

Mean values of final fish weight, specific growth rate, survival and production parameters were compared using one-way analysis of variance (ANOVA), and pair-wise comparison of treatment means was done using Tukey HSD test $(\alpha=0.05)$.

\section{RESULTS AND DISCUSSION}

Water quality data variation over the study period is presented (Table1.1). Water quality parameters were within acceptable ranges for fish culture. There were no significant differences in water quality parameters between the different treatment ponds.

Table 1 Mean water quality parameters measured in various treatment ponds.

\begin{tabular}{cccc}
\hline Parameters & $\mathrm{C}$ & $\begin{array}{c}\text { Treatments } \\
\mathrm{C}+\mathrm{S}\end{array}$ & $\mathrm{C}+\mathrm{S}+\mathrm{F}$ \\
\hline Temperature & 27.3 & 27.0 & 27.2 \\
$\mathrm{pH}$ & $6.5-6.6$ & $6.5-6.6$ & $6.3-6.6$ \\
Water depth $(\mathrm{cm})$ & 50.0 & 50.0 & 50.0 \\
$\mathrm{TDS}(\mathrm{mg} / \mathrm{l})$ & 136.1 & 156.5 & 122.8 \\
$\mathrm{NO}_{3}-\mathrm{N}(\mathrm{mg} / \mathrm{l})$ & 1.4 & 1.4 & 1.3 \\
$\mathrm{NH}_{3}-\mathrm{N}(\mathrm{mg} / \mathrm{l})$ & 1.3 & 1.3 & 1.4 \\
\hline Total alkalinity(mg/l) & 200.0 & 200.0 & 180.0 \\
\hline * Treatments: C; Control, S; substrate installation, F; feeding
\end{tabular}


Catfish yields over the growth period are presented in Table 1.2. The survival of catfish did not vary significantly between treatments, but was generally high, and ranged between 81.2 and $96.8 \%$ (Table 2). On the average, growth rate for catfish in substrate treatments $(\mathrm{C}+\mathrm{S})$ was higher than that of feed and control treatments. The control treatments had the lowest production of catfish. The total net yields from feed and substrate treatments were $29.5 \%$ and $70.4 \%$ higher, respectively, than that of the control treatment. The bamboo poles planted in the ponds provided an additional surface area to enhance periphyton growth for feeding by fish.

Table 2. Mean weight of catfish over a 90-day growth period under varying conditions.

\begin{tabular}{|c|c|c|c|c|c|}
\hline Treatment & $\begin{array}{l}\text { Initial individual } \\
\text { weight }(\mathrm{g})\end{array}$ & $\begin{array}{l}\text { Final individual } \\
\text { weight }(\mathrm{g})\end{array}$ & $\begin{array}{l}\text { Survival } \\
(\%)\end{array}$ & $\begin{array}{l}\text { Gross yield } \\
\left(\mathrm{kg} / 100 \mathrm{~m}^{2}\right)\end{array}$ & $\begin{array}{l}\text { SGR } \\
\left(\% \text { day }^{-1}\right)\end{array}$ \\
\hline $\mathrm{C}$ & $27.5 \pm 1.25$ & $48.0 \pm 9.61$ & $81.3 \pm 16.25$ & 6.0 & $0.50 \pm 0.18$ \\
\hline $\mathrm{C}+\mathrm{S}$ & $27.5 \pm 0.00$ & $101.9 \pm 65.54$ & $96.8 \pm 1.9$ & 16.0 & $1.19 \pm 0.8$ \\
\hline $\mathrm{C}+\mathrm{S}+\mathrm{F}$ & $26.3 \pm 1.25$ & $68.7 \pm 2.63$ & $86.3 \pm 1.25$ & 9.5 & $1.07 \pm 0.1$ \\
\hline
\end{tabular}

\section{DISCUSSION}

The effects of bamboo substrate on fish production in the three treatments, which were manure application as control (C), control and substrate installation (C + $\mathrm{S}$ ), and control and substrate with supplementary feeding $(\mathrm{C}+\mathrm{S}+\mathrm{F})$ provided considerable growth differences among the treatments. Provision of bamboo substrates resulted in $70.4 \%$ greater fish production than in the control (substrate-free) system, whereas supplementary feeding in the same substrate system yielded $29.5 \%$ more than in the control system. The results obtained in this study corroborate similar findings in which fish yields of $66-71 \%$ for substrate treatment than in control system have been documented (Azim et. al., 2002). The highest net yield recorded for the substrate system over the 90day culture period was $10 \mathrm{~kg}$, which was more than fish yield in substrate-free control system and this result also agrees with those found by Wahab et. al., (1999) for Labeo calbasu in periphyton-based culture. Greater percentage of the $10 \mathrm{~kg}$ net yield was contributed by the significant growth performance of catfish. The high yield from catfish may be partly attributed to the high survival percentage $(78 \%)$ in the culture systems.

The study has demonstrated that fish production in the periphyton-based systems was higher than in the substrate-free controls. This could be accounted for by the additional feed provided by the periphyton surfaces (Azim et. al., 2002a; Azim et. al., 2002b). Periphyton is the total assemblage of attached aquatic flora and fauna that are more easily consumed by fish. In traditional fish ponds, as in the case of the substrate-free control, the pond bottom presents the only substrate for benthic algae to grow (Azim et al., 2003). Apparently this produces less food to meet the requirements of most culture species. However, tree branches as additional substrates, provide more algae along with zooplankton which provides natural food to increase fish yield. From an ecological viewpoint, periphyton-based culture represent appropriate natural source of food for fish production (Hem and Avit, 1994) and performs better than the traditional substrate-free systems. Periphyton-based systems offer the potential for increasing natural food as well as nutrient efficiency for higher fish output in enclosed culture systems

\section{REFERENCES}

Azim, M.E., Milstein, A., Wahab, M.A., Verdegem, M.C. J., 2003. Periphyton water quality relationship in fertilized fish ponds with artificial substrates. Aquaculture 228 (2003) 169-187.

Azim, ME; Rahama, MM; Wahab, MA; Asaeda, T; Little, DC; Verdegem, MCJ (2004). Periphyton based pond polyculture system; bioeconomic comparison of on farm and on station trials. Aquacult. Res. 222 (2004); 237-243.

Azim, ME; Verdegem, MCJ; Khaton, H; Wahab, M.A; Van Dam AA; Beveridge, MCM (2002a) A comparison of fertilization, feeding and three periphyton substrate for increasing fish production in freshwater pond aquaculture in Bangladesh. Aquacult. Res. 212 (2002); 227243.

Azim, ME; Wahab, MA., Van Dam, AA; Van Rooij, JM; Beveridge, MCM., Verdegem, MCS (2002b). The effects of artificial substrate on freshwater pond productivity and water quality and the implications for periphyton based aquaculture. Aquat. Living Resour. 15 (4), 231241.

Azim, ME; Wahab, MA; Van Dam, AA; Beveridge, MCM; Verdegem, MCJ. (2001). Optimization of fertilization rate for maximizing periphyton production on artificial substrate and the implication for periphyton based aquaculture. Aquat. Res. 32,749-760. 
Hem, S; Avit, JLB (1994). First result on acadjas enclos as an extensive aquaculture system (West Africa) Bull. Mar. Sci 55, 1038-1049

Mensah, MA; Koranteng, KA; Yeboah, D; Bortey, A (2003). Study of the impact of international trade in fishery products on food security. The case of Ghana. Report.

MOFA: Directorate of fisheries, 2004. Information on fisheries in Ghana. Ministry of food and Agriculture. Ghana.
Wahab, MA., Azim, ME; Ali, M.H; Beveridge, MCM; Khan, S (1999). The potential of periphyton based culture of a native major carp, Labeo calbusa. Aquaculture. Res. 30,409-420.

Welcomme, RL (1972). An evaluation of acadja method of fishing as practice in the coastal lagoons of Dahomey (West Africa) J. Fish Biol. $439-55$. 